\title{
PENGARUH PENAMBAHAN TEPUNG AMPAS TAHU TERHADAP KADAR PROTEIN, KADAR SERAT, KADAR AIR DAN DAYA TERIMA BAKSO IKAN NILA (Oreochromis Niloticus)
}

\section{The Effect of Tofu Waste Flour Addition on Protein, Fiber, Water Content and Acceptability of Tilapia (Oreochromis Niloticus) Fish Meatballs}

\author{
Syafrilia Fillaili, Farida Wahyu Ningtyias*, Sulistiyani \\ Program Studi Kesehatan Masyarakat, Fakultas Kesehatan Masyarakat, Universitas Jember \\ Naskah masuk: 29 Desember 2019 Perbaikan: 27 Agustus 2020 Layak terbit: 15 Oktober 2020 \\ https://doi.org/10.22435/hsr.v23i4.2604
}

\begin{abstract}
ABSTRAK
Gerakan Memasyarakatkan Makan Ikan (GEMARIKAN) merupakan suatu usaha untuk meningkatkan konsumsi ikan serta perbaikan gizi masyarakat melalui konsumsi produk perikanan. Upaya yang dapat dilakukan untuk mendukung GEMARIKAN adalah dengan melakukan modifikasi pengolahan ikan untuk menambah variasi produk perikanan maupun memperkaya kandungan gizinya. Bahan yang digunakan dalam modifikasi produk perikanan pada penelitian ini adalah ikan nila dan tepung ampas tahu yang kemudian diolah menjadi bakso ikan nila. Penelitian bertujuan menganalisis pengaruh penambahan tepung ampas tahu terhadap kadar protein, kadar serat, kadar air dan daya terima pada bakso ikan nila. Penelitian ini merupakan penelitian eksperimen dengan jenis quasi eksperimental menggunakan desain penelitian posttest only control group design. Hasil penelitian menunjukkan seiring peningkatan jumlah penambahan tepung ampas tahu $\left(\mathrm{X}_{0}\right.$ : 0 gram; $X_{1}: 5$ gram; $X_{2}: 10$ gram; $X_{3}: 15$ gram) meningkatkan kadar protein, serat dan air bakso ikan nila. Kadar protein menjadi $X_{0}: 16,59 \% ; X_{1}: 16,88 \% ; X_{2}: 17,24 \% ; X_{3}: 17,42 \%$; kadar serat menjadi $X_{0}: 0,08 \% ; X_{1}: 0,14 \% ; X_{2}: 0,25 \% ; X_{3}: 0,35 \%$; dan kadar air menjadi $\mathrm{X}_{0}: 63,63 \% ; \mathrm{X}_{1}: 63,55 \% ; \mathrm{X}_{2}: 63,75 \% ; \mathrm{X}_{3}: 64,07 \%$. Bakso yang disarankan adalah bakso ikan nila dengan penambahan tepung ampas tahu sebanyak 10 gram. Perlakuan ini menghasilkan bakso ikan nila yang paling banyak disukai oleh panelis dan dari segi mutu gizinya telah sesuai dengan standar mutu bakso ikan.
\end{abstract}

Kata Kunci: bakso ikan; ikan nila; protein; serat; tepung ampas tahu

\begin{abstract}
Gerakan Memasyarakatkan Makan Ikan (GEMARIKAN) is launched as an effort to increase fish consumption and improve people's nutrition through the consumption of fishery products. Food processing modification is an effort to support GEMARIKAN by increasing food processing method to improve fishery products' nutrition. Tilapia and tofu waste flour are used as ingredients in making tilapia fish meatballs. This study aims to analyze the effect of the addition of tofu waste flour on protein, fiber, water content, and acceptability of tilapia fish meatballs. This research was experimental research with a quasi-experimental type and used a posttest only control group research design. The addition of tofu waste flour $\left(X_{0}: 0\right.$ gram; $X_{1} ; 5$ grams; $X_{2}: 10$ grams; $X_{3}: 15$ grams) caused the increasing level of protein, fiber, and water of tilapia fish meatballs. Protein content on tilapia fish meatballs are $X_{0}: 16.59 \% ; X_{1}: 16.88 \% ; X_{2}: 17.24 \% ; X_{3}: 17.42 \%$, fiber content are $\left.X_{0}: 0.08 \% ; X_{1}: 0.14 \% ; X_{2}: 0.25 \% ; X_{3}: 0.35 \%\right)$ and water content were $X_{0}: 63.63 \% ; X_{1}: 63.55 \% ; X_{2}$ : $\left.63.75 \% ; X_{3}: 64.07 \%\right)$. Tilapia fish meatballs with 10 grams addition of tofu waste flour were the most acceptable product. This innovation produced the most preferred meatball product by panelists, and the nutritional content had met the fish meatball's quality standards.
\end{abstract}

Keywords: fish meatballs; fiber; protein; tilapia, tofu waste flour

Korespondensi:

Farida Wahyu Ningtyias

Program Studi Kesehatan Masyarakat, Fakultas Keshatan Masyarakat, Universitas Jember

E-mail: farida.fkm@unej.ac.id 


\section{PENDAHULUAN}

Gerakan Memasyarakatkan Makan Ikan (GEMARIKAN) merupakan program nasional yang dicanangkan pemerintah untuk memotivasi masyarakat agar mengkonsumsi ikan secara teratur dalam jumlah yang baik bagi kesehatan sehingga terbentuk manusia yang sehat, cerdas, dan kuat. Ikan merupakan salah satu sumber protein alternative yang tersedia dalam jumlah cukup banyak. Indonesia memiliki potensi sumber daya perikanan yang besar baik ikan laut maupun ikan air tawar. Salah satu upaya pendukung yang dapat dilakukan adalah dengan melakukan modifikasi pengolahan produk berbahan dasar ikan. Modifikasi pengolahan dilakukan untuk menambah variasi produk serta memperkaya kandungan gizi dari produk perikanan (Kementerian Kelautan dan Perikanan, 2017; Gunawan, Kuntjara, \& Sutanto, 2017; Prameswari, Kurnia, \& Susilo, 2019).

Ikan merupakan salah satu komoditi bahan makanan bergizi karena mengandung protein yang tinggi. Konsumsi ikan dan makanan laut lainnya yang sehat dan tidak tercemar logam berat dapat menyehatkan tubuh dan meningkatkan kemampuan otak. Nilawati menjelaskan kurangnya konsumsi makanan berprotein merupakan salah satu faktor yang dapat menyebabkan terjadinya kekurangan gizi dan menghambat perkembangan kognisi (Bimantara \& Anindita, 2018; Zulaihah \& Widajanti, 2012). Ikan nila merupakan salah satu komoditas perikanan yang populer di masyarakat. Ikan nila menjadi salah satu komoditas perikanan air tawar yang banyak dikembangkan di Kabupaten Jember, Jawa Timur. Data Dinas Peternakan, Perikanan dan Kelautan Jember menunjukkan produksi ikan nila di Jember, Jawa Timur terus mengalami peningkatan. Tahun 2012 produksi ikan nila sebesar 187,8 ton, tahun 2013 sebesar 189 ton, dan meningkat lagi menjadi 265 ton pada tahun 2014 (Pemerintah Kabupaten Jember, 2014).

Kedelai merupakan salah satu bahan pangan nabati yang banyak mengandung protein dan serat pangan dibandingkan sumber serat lainnya. Protein pada kedelai mengandung semua jenis asam amino yang hampir setara dengan protein hewani namun rendah lemak jenuh (Suryandari \& Widyastuti, 2015). Lemak jenuh merupakan lemak jahat yang dapat diubah menjadi kolesterol sehingga peningkatan konsumsi lemak jenuh dapat menyebabkan peningkatan low density lipoprotein (LDL) (Yuliantini, Sari, \& Nur, 2015). Serat kedelai mengandung sekitar 75 persen serat pangan. Tahu merupakan salah satu produk utama olahan kedelai. Proses produksi tahu menghasilkan produk sampingan berupa ampas tahu dan whey. Ampas tahu seringkali dibuang karena dianggap limbah dan tidak memiliki manfaat lagi. Padahal ampas tahu mengandung protein sebesar 17,4 gram per 100 gram bahan serta serat larut sebesar 3,52 persen pada ampas tahu basah dan 12,2 persen pada ampas tahu kering ( $\mathrm{Li}, \mathrm{Zhu}, \mathrm{Li}$, Yang, Lei, \& Zhang, 2013; Suprapti, 2005). Ampas tahu memiliki kandungan air sebesar 84,1 persen. Kandungan air menyebabkan ampas tahu mudah rusak. Upaya yang dapat dilakukan adalah dengan mengeringkan ampas tahu dan mengolahnya menjadi tepung ampas tahu (Kementerian Kesehatan RI, 2018) (Yustina \& Abadi, 2012). Tepung ampas tahu memiliki kandungan protein sebesar 17,72 persen dan serat kasar sebesar 3,23 persen (Wati, 2013).

Pembuatan bakso berbahan dasar daging ikan dapat menjadi salah satu alternatif modifikasi pengolahan hasil perikanan sebagai upaya memperkaya keanekaragaman produk hasil perikanan. Bakso merupakan salah satu olahan daging secara tradisional yang berbahan dasar daging seperti daging sapi, ayam maupun ikan. Bakso merupakan makanan lezat yang memiliki kandungan gizi tinggi salah satunya adalah protein (Pramudya, Julianti, \& Lubis, 2014; Salman, Syainah, \& Rezkiah, 2018). Jenis ikan yang cocok digunakan sebagai bahan baku pembuatan bakso adalah ikan yang tidak memiliki duri menyebar sehingga mudah untuk dipisahkan dari dagingnya. Selain itu, fillet daging ikan segar juga dapat digunakan dalam pembuatan bakso ikan. Indraswari menyebutkan sebaiknya dipilih ikan yang berukuran besar agar lebih mudah dalam proses pemisahan daging dari tulangnya. Hal tersebut guna menjamin keamanan pangan pada produk yang dihasilkan (Indraswari, Ningtyias, \& Rohmawati, 2017).

Ikan nila memiliki karakteristik daging tebal dan tidak mengandung duri kecil dalam dagingnya sehingga dapat menjadi salah satu jenis ikan yang cocok digunakan sebagai bahan dasar pembuatan bakso (Rukmana \& Herdi, 2015). Ikan nila memiliki kandungan protein lebih tinggi jika dibandingkan dengan beberapa jenis ikan lainnya seperti lele, gurami, tongkol dan cakalang. Kandungan protein dalam 100 gram ikan nila yaitu 20,08 persen. Ikan nila merupakan bahan pangan yang mengandung protein dan asam amino yang diperlukan oleh tubuh. Serat protein pada ikan nila lebih rendah sehingga lebih mudah dicerna. Suatu pangan dianggap 
sebagai sumber protein apabila mengandung protein minimal 20 persen dalam bentuk padat. (Kementerian Kesehatan RI, 2018) (United States Departement of Agriculture Food, 2010). Konsumsi pangan yang mengandung zat gizi cukup dan aman dikonsumsi dapat menjadi salah satu langkah untuk mencapai status gizi yang baik (Adriani \& Kartika, 2013).

Selain untuk memperkaya keanekaragaman macam produk perikanan, modifikasi pengolahan hasil perikanan juga memiliki tujuan memperkaya kandungan gizi dari produk perikanan (Kementerian Kelautan dan Perikanan, 2017). Hermana menyebutkan konsumsi pangan yang mengandung zat gizi cukup dan aman dikonsumsi dapat menjadi salah satu langkah untuk mencapai status gizi yang baik, sedangkan tidak tersedianya zat-zat gizi dalam kualitas dan kuantitas yang cukup untuk memenuhi kebutuhan tubuh dapat menyebabkan kurang gizi (Adriani \& Kartika, 2013). Ikan nila merupakan pangan sumber protein namun rendah serat. Penambahan tepung ampas tahu dalam pembuatan bakso ikan dapat menjadi salah satu bentuk alternatif dalam modifikasi pengolahannya. Protein hewani mengandung asam amino lengkap dan lebih mudah disintesis tubuh. Sedangkan protein nabati merupakan protein rendah lemak jenuh, rendah kolesterol serta mengandung serat dan karbohidrat kompleks. Oleh karena itu, agar kualitas protein dalam suatu hidangan dapat terpenuhi, sebaiknya dicampur antara protein hewani dan nabati. Konsumsi makanan beragam dapat saling melengkapi kebutuhan zat gizi bagi tubuh. Kandungan protein nabati dan serat pada tepung ampas tahu dapat berkontribusi untuk memperkaya gizi produk bakso ikan (Aprilia \& Hati, 2016; Suryandari \& Widyastuti, 2015).

Berdasarkan data tersebut, peneliti tertarik untuk melakukan modifikasi pengolahan ikan nila menjadi bakso dengan menambahkan tepung ampas tahu sebagai upaya memperkaya kandungan gizi bakso ikan nila. Produk bakso ikan nila kemudian diteliti mengenai kandungan gizi dan kesesuaiannya dengan syarat mutu bakso ikan. Selain itu, diteliti juga mengenai daya terima serta peranannya dalam pemenuhan Angka Kecukupan Gizi (AKG) bagi konsumen. Peneliti tertarik untuk membuat formulasi bakso ikan nila dengan penambahan tepung ampas tahu sebanyak 0 gram, 5 gram, 10 gram dan 15 gram. Tujuan dari penelitian ini adalah menganalisis pengaruh penambahan tepung ampas tahu terhadap kadar protein, serat, air dan daya terima yang meliputi kenampakan, aroma, rasa dan tekstur bakso ikan nila.

\section{METODE}

Penelitian ini menggunakan metode penelitian eksperimen (experimental research). Tujuan dari penelitian eksperimental adalah untuk mengetahui gejala atau pengaruh yang timbul sebagai akibat dari adanya perlakuan tertentu atau eksprimen yang dilakukan. Jenis penelitian yang digunakan adalah quasi eksperimental (eksperimen semu) dengan desain penelitian posttest only control group design. Subjek penelitian dibagi menjadi kelompok kontrol dan kelompok yang mendapat perlakuan. Kedua kelompok dianggap sama sebelum diberi perlakuan karena tidak ada pretest (Notoadmodjo, 2012).

Sampel dari penelitian ini adalah bakso ikan nila dengan penambahan tepung ampas tahu sebanyak 0 gram, 5 gram, 10 gram, dan 15 gram. Sampel direplikasi sebanyak 6 replikasi sehingga total terdapat 24 unit percobaan. Pengujian kandungan protein menggunakan metode Semi Mikro Kjeldahl, pengujian kandungan serat menggunakan metode Gravimetri, dan pengujian kandungan air menggunakan metode Destilasi. Uji laboratorium dilakukan di Laboratorium Analisis Pangan Politeknik Negeri Jember. Sedangkan uji daya terima (Hedonic Scale Test) dilakukan di SD Negeri Slawu 01 Jember. Panelis uji daya terima terdiri atas 25 siswa sekolah dasar kelas IV dengan rentang usia 10 tahun sampai 11 tahun. Penelitian dilaksanakan sejak bulan Mei 2019.

Penelitian ini menggunakan dua macam variabel penelitian yakni variabel bebas (independent variable) dan variabel terikat (dependent variable). Variabel bebas penelitian ini adalah penambahan tepung ampas tahu, sedangkan variabel terikat adalah kadar protein, kadar serat, kadar air dan daya terima bakso ikan nila. Sumber data primer penelitian ini yaitu hasil laboratorium kadar protein, kadar serat dan kadar air serta hasil uji daya terima bakso ikan nila pada keempat kelompok perlakuan. Hasil laboratorium kadar protein, serat dan air bakso ikan nila dianalisis menggunakan uji statistik Kruskal Wallis. Jika hasil uji signifikan, pengujian dilanjutkan dengan uji statistik Mann Whitney untuk mengetahui perbedaan dari keempat kelompok perlakuan. Sedangkan hasil uji daya terima bakso ikan nila dianalisis menggunakan uji statistik Friedman. Jika hasil uji signifikan, pengujian dilanjutkan dengan uji Wilcoxon Sign Rank Test untuk mengetahui perbedaan daya terima yang meliputi kenampakan, aroma, rasa dan tekstur dari bakso ikan nila pada keempat kelompok perlakuan. 
HASIL

Berdasarkan hasil uji laboratorium kadar protein, kadar serat dan kadar air bakso ikan nila didapatkan hasil semakin banyak jumlah tepung ampas tahu yang ditambahkan, maka semakin meningkat pula kadar protein, serat dan air bakso ikan nila. Sedangkan data hasil uji daya terima menunjukkan adanya perbedaan tingkat kesukaan dari masingmasing panelis terhadap produk bakso ikan nila yang dihasilkan dari keempat kelompok perlakuan.

\section{Pengaruh Penambahan Tepung Ampas Tahu terhadap Kadar Protein Bakso Ikan Nila}

Berdasarkan hasil uji analisis kadar protein bakso ikan nila, diketahui bahwa rata-rata kadar protein yang terkandung dalam bakso ikan nila kelompok perlakuan $X_{0}, X_{1}, X_{2}$, dan $X_{3}$ berkisar antara 16,59 persen sampai 17,42 persen. Kadar protein meningkat seiring peningkatan jumlah tepung ampas tahu yang ditambahkan pada bakso ikan nila.

\section{Pengaruh Penambahan Tepung Ampas Tahu terhadap Kadar Serat Bakso Ikan Nila}

Berdasarkan hasil uji analisis kadar serat bakso ikan nila, diketahui bahwa rata-rata kadar serat yang terkandung dalam bakso ikan nila kelompok perlakuan $\mathrm{X}_{0}, \mathrm{X}_{1}, \mathrm{X}_{2}$, dan $\mathrm{X}_{3}$ berkisar antara 0,08 persen sampai 0,35 persen. Kadar serat meningkat seiring peningkatan jumlah tepung ampas tahu yang ditambahkan pada bakso ikan nila.

\section{Pengaruh Penambahan Tepung Ampas Tahu terhadap Kadar Air Bakso Ikan Nila}

Berdasarkan hasil uji analisis kadar air bakso ikan nila, diketahui bahwa rata-rata kadar air yang terkandung dalam bakso ikan nila kelompok perlakuan $\mathrm{X}_{0}, \mathrm{X}_{1}, \mathrm{X}_{2}$, dan $\mathrm{X}_{3}$ berkisar antara 63,63 persen sampai 64,07 persen. Kadar air pada masingmasing perlakuan menunjukkan perbedaan. Secara umum, kadar air meningkat seiring peningkatan jumlah tepung ampas tahu yang ditambahkan pada bakso ikan nila.

\section{Pengaruh Penambahan Tepung Ampas Tahu terhadap Daya Terima Bakso Ikan Nila}

Berdasarkan hasil uji daya terima (hedonic scale test) bakso ikan nila pada 25 panelis pengujian, secara umum bakso ikan nila pada kelompok perlakuan $\mathrm{X}_{0}, \mathrm{X}_{1}, \mathrm{X}_{2}$, dan $\mathrm{X}_{3}$ dapat diterima oleh panelis. Kelompok perlakuan bakso ikan nila yang memperoleh skor daya terima tertinggi baik dari aspek kenampakan, aroma, rasa dan tekstur adalah $\mathrm{X}_{2}$. Kelompok perlakuan $\mathrm{X}_{2}$ merupakan bakso ikan nila yang diberi tambahan tepung ampas tahu sebanyak 10 gram.

Hasil uji daya terima (hedonic scale test) bakso ikan nila pada 25 panelis pengujian kemudian dianalisis menggunakan uji Friedman dengan tingkat signifikansi sebesar 0,05. Analisis daya terima kenampakan menggunakan uji Friedman menghasilkan $p$ value $(0,093)>\alpha(0,05)$. Sedangkan untuk $p$ value daya terima aroma, rasa dan tekstur bakso ikan nila secara berturut-turut adalah 0,032 0,$031 ; 0,038$. Sehingga menghasilkan $p$ value $<\alpha$. Artinya daya terima kenampakan bakso ikan nila pada kelompok perlakuan $\mathrm{X}_{0}, \mathrm{X}_{1}, \mathrm{X}_{2}$, dan $\mathrm{X}_{3}$ sama Sedangkan untuk aspek aroma, rasa, dan tekstur terdapat perbedaan terhadap daya terimanya.

Berdasarkan hasil analisis uji Wilcoxon Signed Ranks Test diperoleh hasil kelompok perlakuan yang saling berbeda secara nyata berdasarkan aspek aroma adalah $\mathrm{X}_{1}$ dibandingkan dengan kelompok perlakuan $X_{2}$. Kelompok perlakuan yang saling berbeda secara nyata berdasarkan aspek rasa adalah kelompok perlakuan $\mathrm{X}_{0}$ dibandingkan dengan kelompok perlakuan $\mathrm{X}_{2}$. Sedangkan untuk aspek tekstur, kelompok perlakuan yang berbeda secara nyata yaitu kelompok perlakuan $\mathrm{X}_{0}$ dibandingkan dengan kelompok perlakuan $\mathrm{X}_{2}$ dan kelompok perlakuan $\mathrm{X}_{0}$ dibandingkan dengan kelompok perlakuan $\mathrm{X}_{3}$.

Tabel 1. Proporsi Penambahan Tepung Ampas Tahu

\begin{tabular}{ccccc}
\hline No. & Kelompok & Ikan Nila & Tepung Tapioka & Tepung Ampas Tahu \\
\hline 1. & Kontrol & $250 \mathrm{gram}$ & $50 \mathrm{gram}$ & $0 \mathrm{gram}$ \\
2. & Eksperimen & $250 \mathrm{gram}$ & $50 \mathrm{gram}$ & $5 \mathrm{gram}$ \\
3. & & $250 \mathrm{gram}$ & $50 \mathrm{gram}$ & $10 \mathrm{gram}$ \\
4. & $250 \mathrm{gram}$ & $50 \mathrm{gram}$ & $15 \mathrm{gram}$ \\
\hline
\end{tabular}


Pengaruh Penambahan Tepung Ampas Tahu (Syafrilia Fillaili, dkk.)

Tabel 2. Kadar Protein, Serat, dan Air Bakso Ikan Nila pada Keempat Perlakuan

\begin{tabular}{lccccc}
\hline Hasil Uji & $\mathbf{X}_{\mathbf{0}}$ & $\mathbf{X}_{\mathbf{1}}$ & $\mathbf{X}_{\mathbf{2}}$ & $\mathbf{X}_{\mathbf{3}}$ & Nilai $\boldsymbol{p}$ value Uji Kruskal Wallis \\
\hline Kadar Protein (\%) & 16,59 & 16,88 & 17,24 & 17,42 & $0,000^{*}$ \\
Kadar Serat (\%) & 0,08 & 0,14 & 0,25 & 0,35 & $0,000^{*}$ \\
Kadar Air (\%) & 63,63 & 63,55 & 63,75 & 64,07 & $0,002^{*}$ \\
\hline
\end{tabular}

$\left(^{*}\right)$ terdapat perbedaan yang signifikan pada taraf uji $p$ value $\leq 0,05$

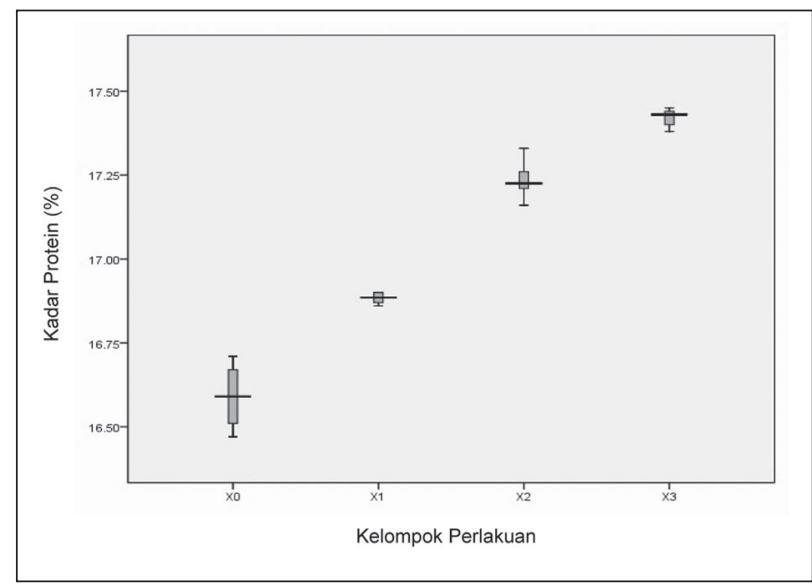

Gambar 1. Grafik Kadar Protein Bakso Ikan Nila

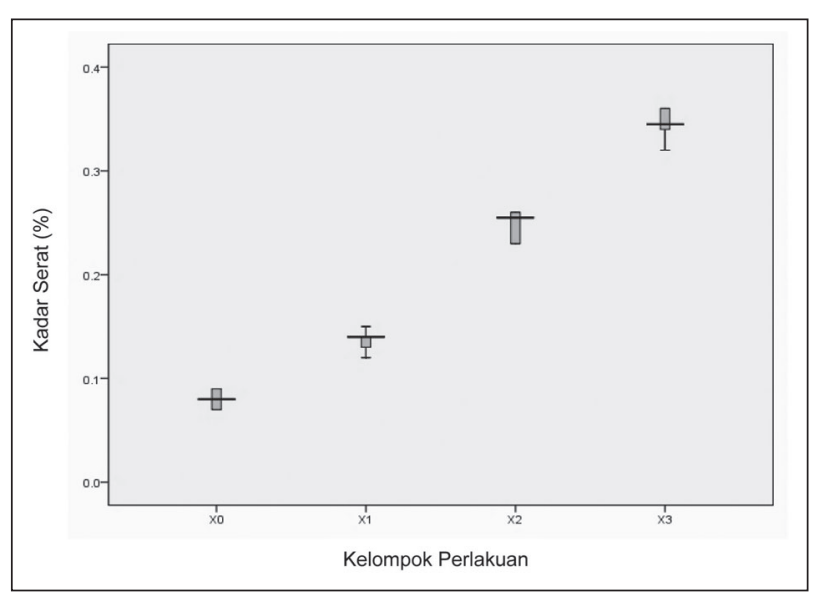

Gambar 2. Grafik Kadar Serat Bakso Ikan Nila

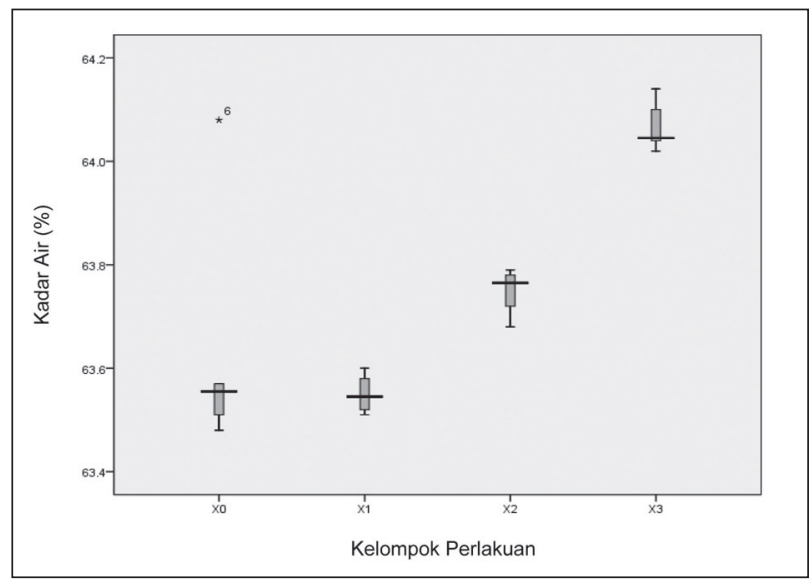

Gambar 3. Grafik Kadar Air Bakso Ikan Nila

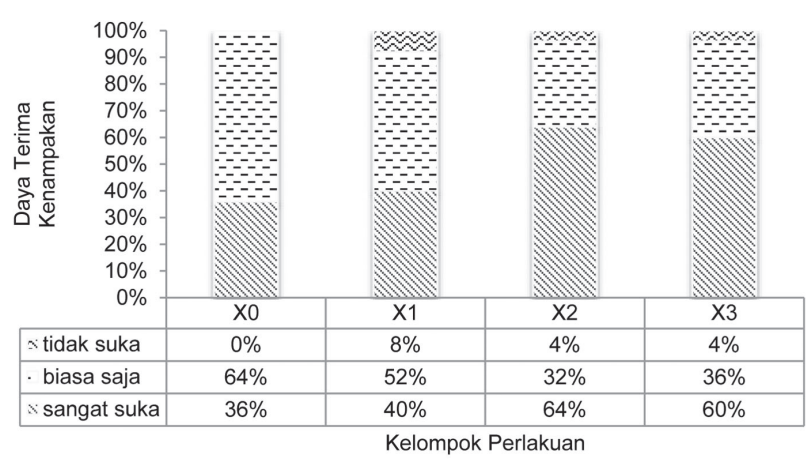

Gambar 4. Hasil Uji Daya Terima Kenampakan Bakso Ikan Nila

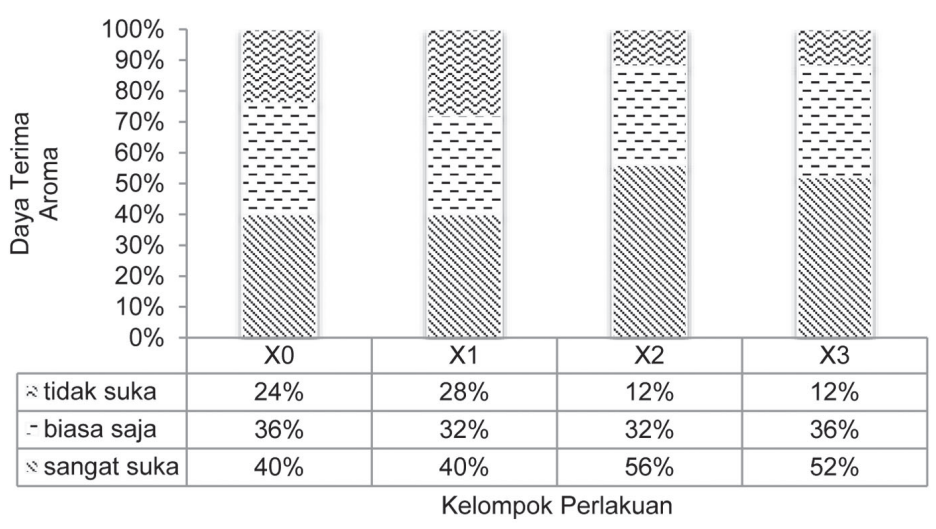

Gambar 5. Hasil Uji Daya Terima Aroma Bakso Ikan Nila 


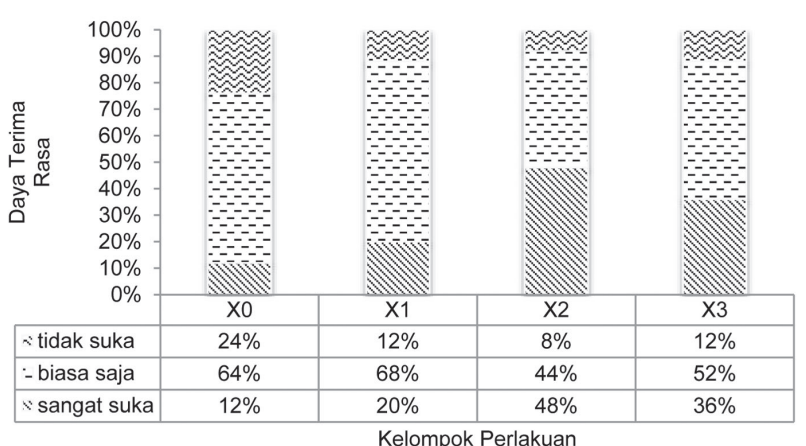

Gambar 6. Hasil Uji Daya Terima Rasa Bakso Ikan Nila

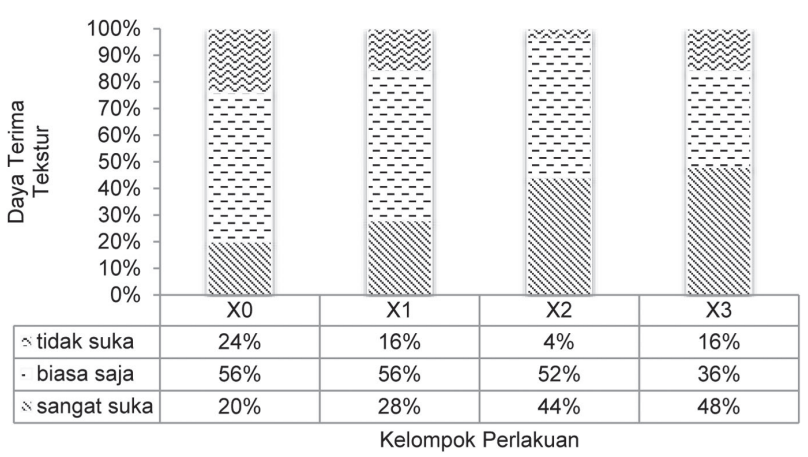

Gambar 7. Hasil Uji Daya Terima Tekstur Bakso Ikan Nila

\section{PEMBAHASAN}

\section{Pengaruh Penambahan Tepung Ampas Tahu terhadap Kadar Protein Bakso Ikan Nila}

Protein merupakan susunan dari sejumlah L-asam amino yang dihubungkan dengan ikatan peptida membentuk makromolekul peptida. Protein merupakan komponen makro molekul yang dibutuhkan oleh setiap makhluk hidup. Fungsi utama protein yaitu sintesis protein-protein baru. Protein merupakan bagian terbesar dalam tubuh setelah air. Sebanyak setengah dari jumlah protein dalam tubuh disimpan dalam otot, seperlima dalam tulang dan tulang rawan, sepersepuluh dalam kulit, dan selebihnya disimpan dalam jaringan lainnya dan cairan tubuh (Rismayanthi, 2006; Susanti \& Hidayat, 2016).

Protein terdapat dalam makanan baik yang dari sumber hewani maupun nabati. Contoh makanan sumber protein hewani yaitu telur, susu, daging dan ikan. Sedangkan sumber protein nabati contohnya kacang-kacangan. Protein dibutuhkan dalam proses pertumbuhan dan perkembangan. Mengkonsumsi makanan yang beraneka ragam dalam kehidupan sehari-hari merupakan cara untuk memenuhi kebutuhan asam amino bagi tubuh. Susunan hidangan yang beragam dapat menupi kekurangan asam amino pada suatu jenis makanan dengan makanan lainnya yang memiliki kelebihan asam amino (Diana, 2010; Rismayanthi, 2006).

Kadar protein bakso ikan nila pada kelompok perlakuan $X_{0}, X_{1}, X_{2}$, dan $X_{3}$ secara berturut-turut adalah 16,59 persen; 16,88 persen; 17,24 persen; dan 17,42 persen. Kadar protein terendah terdapat pada perlakuan $\mathrm{X}_{0}$ yaitu bakso ikan nila dengan penambahan tepung ampas tahu sebesar 0 gram. Sedangkan kadar protein bakso ikan nila tertinggi terdapat pada perlakuan $\mathrm{X}_{3}$ yaitu bakso ikan nila dengan penambahan tepung ampas tahu sebesar 15 gram. Kadar protein bakso ikan nila mengalami peningkatan mulai dari $\mathrm{X}_{0}, \mathrm{X}_{1}, \mathrm{X}_{2}$, sampai $\mathrm{X}_{3}$. Artinya, kadar protein pada bakso ikan nila mengalami peningkatan seiring dengan peningkatan jumlah tepung ampas tahu yang ditambahkan pada bakso ikan nila. kedelai sebagai bahan dasar ampas tahu dapat menyumbangkan banyak protein dan zat gizi lainnya di kalangan masyarakat negara maju dan berkembang. Subtitusi kedelai pada kudapan ekstrusi jagung dapat meningkatkan kadar protein seiring bertambahnya jumlah kedelai yang disubstitusikan (Rudini \& Ayustaningwarno, 2013). Kandungan protein minimal bakso ikan berdasarkan syarat mutu dalam SNI Bakso Ikan adalah 7 gram per 100 gram bahan (Badan Standarisasi Nasional, 2014). Sehingga dapat disimpulkan, kandungan protein pada bakso ikan nila dengan penambahan tepung ampas tahu telah sesuai dengan syarat mutu bakso ikan.

Perbedaan jumlah penambahan ampas tahu berpengaruh terhadap kadar protein yang dikandung oleh bakso ikan nila. Hasil analisis kandungan protein menggunakan uji Kruskal Wallis dan uji Mann Whitney menunjukkan terdapat perbedaan pada setiap kelompok perlakuan bakso ikan nila yang saling dibandingkan. Kaahoao meneliti manfaat tepung ampas tahu dalam pembuatan kukis. Hasil penelitian menunjukkan peningkatan protein terjadi seiring bertambahnya tepung ampas tahu yang digunakan dalam pembuatan kukis. Peningkatan kadar protein terjadi karena kandungan protein yang tinggi pada tepung ampas tahu dapat menyumbangkan protein pada kukis (Kaahaoao, Herawati, \& Ayu, 2017).

\section{Pengaruh Penambahan Tepung Ampas Tahu terhadap Kadar Serat Bakso Ikan Nila}

Serat adalah bagian tumbuhan yang dapat dikonsumsi. Tersusun dari karbohidrat yang memiliki sifat resistan terhadap proses pencernaan dan 
penyerapan dalam usus halus serta mengalami fermentasi sebagian atau keseluruhan di dalam usus besar (Santoso, 2011). Serat termasuk bagian makanan yang tidak mudah diserap namun memiliki fungsi yang tidak dapat digantikan oleh zat lain. Waspadji menyebutkan serat berfungsi dalam pelepasan hormon intestinal, mengikat kalsium, zat besi, seng, dan zat organik lainnya seperti asam empedu dan kolesterol dalam siklus enterohepatik kolesterol. Selain itu, konsumsi serat yang cukup dapat membantu mengontrol gula darah. Makanan berserat dapat memberikan serat pangan, vitamin, mineral dan substansi lain yang penting bagi kesehatan. Serat dalam makanan biasanya disebut dengan dietary fiber. Serat makanan tidak hanya terdapat pada sayur-sayuran dan buah-buahan, tetapi juga dalam makanan lain seperti beras, kacangkacangan serta umbi-umbian (Azrimaidaliza, 2011; Kusharto, 2006).

Dietary fiber (serat pangan) memiliki mekanisme khusus untuk menurunkan kadar kolesterol dan mengontrol kegemukan sehingga dapat mencegah kondisi hiperkolesterol pada penderita overweightobesitas (Fairudz \& Nisa, 2015). Individu dengan kadar kolesterol total yang tinggi dalam darah memiliki risiko 3,41 kali terkena Diabetes Mellitus (DM) dibandingkan individu dengan kadar kolesterol total yang normal. Selain itu, kolesterol juga merupakan salah satu faktor risiko terjadinya stroke. Kolesterol tinggi memungkinkan kolesterol tertimbun di dinding pembuluh darah sehingga menyebabkan penyempitan pembuluh darah yang dapat mengganggu suplai darah ke otak (stroke) (Puspita \& Putro, 2008).

Berdasarkan Index Massa Tubuh (IMT), individu dengan berat badan kegemukan memiliki risiko 1,98 kali terkena DM dibandingkan individu dengan berat badan normal (Nainggolan, Kristanto, \& Edison, 2013). Selain itu, obesitas juga menjadi faktor risiko terjadinya penyakit jantung coroner (PJK). Angka PJK meningkat seiring dengan peningkatan obesitas yang berlebihan (Rustika \& Oemiati, 2014). Serat juga berperan dalam membantu mengontrol gula darah. Kadar gula darah puasa memiliki risiko sekitar 3,35 menjadi DM dibandingkan dengan kadar gula darah normal (Sirait, Sulistiowati, Sihombing, Kusuma, \& Idayani, 2015).

Kadar serat bakso ikan nila kelompok perlakuan $\mathrm{X}_{0}, \mathrm{X}_{1}, \mathrm{X}_{2}$ dan $\mathrm{X}_{3}$ secara berturut-turut adalah 0,08 persen; 0,14 persen; 0,25 persen; dan 0,35 persen. Kadar serat terendah terdapat pada perlakuan $\mathrm{X}_{0}$ yaitu bakso ikan nila dengan penambahan tepung ampas tahu sebesar 0 gram. Sedangkan kadar serat bakso ikan nila tertinggi terdapat pada perlakuan $\mathrm{X}_{3}$ yaitu bakso ikan nila dengan penambahan tepung ampas tahu sebesar 15 gram. Kadar serat bakso ikan nila mengalami peningkatan mulai dari $\mathrm{X}_{0}, \mathrm{X}_{1}, \mathrm{X}_{2}$, sampai $X_{3}$. Artinya, kadar serat pada bakso ikan nila mengalami peningkatan seiring dengan peningkatan jumlah tepung ampas tahu yang ditambahkan pada bakso ikan nila. Suatu produk pangan dapat disebut sebagai sumber serat apabila mengandung minimal 3 gram 100 gram bahan dalam bentuk padat dan 1,5 gram per 100 gram bahan dalam bentuk cair (Badan Pengawas Obat dan Makanan, 2016). Berdasarkan kandungan seratnya, dapat disimpulkan bahwa bakso ikan nila belum dapat disebut sebagai produk pangan sumber serat. Hal ini dapat disebabkan karena masih rendahnya kandungan serat pada bahan dasar pembuatan bakso ikan nila. Selain itu, jumlah tepung ampas tahu yang ditambahkan tidak banyak sehingga tidak terlalu memberikan pengaruh besar dalam peningkatan kadar serat bakso ikan nila yang dihasilkan.

Perbedaan jumlah penambahan ampas tahu berpengaruh terhadap kadar serat yang terkandung dalam bakso ikan nila. Hasil analisis kandungan serat menggunakan uji Kruskal Wallis dan uji Mann Whitney menunjukkan terdapat perbedaan pada setiap kelompok perlakuan bakso ikan nila yang saling dibandingkan. Putri dan Yuwono menganalisis mengenai pengaruh penambahan tepung ampas tahu dan jenis koagulan pada pembuatan tahu. Penelitian menghasilkan kecenderungan peningkatan kadar serat pada tahu yang dihasilkan seiring dengan semakin banyaknya tepung ampas tahu yang ditambahkan. Peningkatan kadar serat dalam tahu disebabkan tepung ampas tahu yang ditambahkan mengandung serat kasar yang relatif tinggi (Putri \& Yuwono, 2016). Selain itu, ampas tahu berasal dari kacang kedelai yang memiliki kandungan serat cukup tinggi. Substitusi kedelai mampu meningkatkan kadar serat pada kudapan ekstrusi jagung. Kadar serat pada kudapan meningkat seiring dengan semakin banyak jumlah kedelai yang disubstitusikan (Rudini \& Ayustaningwarno, 2013).

\section{Pengaruh Penambahan Tepung Ampas Tahu terhadap Kadar Air Bakso Ikan Nila}

Air tekandung dalam semua bahan makanan baik makanan nabati atau makanan hewani. Berdasarkan keterikatannya, air dibagi menjadi empat kelompok. Tipe I yaitu air yang terikat kuat, tipe II yaitu molekul- 
molekul air yang membentuk ikatan hidrogen dalam mikrokapiler, tipe III yaitu air bebas, dan tipe IV adalah air yang tidak terikat. Air bebas dinyatakan dalam $\mathrm{a}_{\mathrm{w}}$ (water activity). Air tipe ini merupakan air pada permukaan bahan padat, mudah dihilangkan, dan dapat dimanfaatkan sebagai media pertumbuhan mikroba (Amanto, Siswanti, \& Atmaja, 2015; Riyadi, Amanto, \& Basito, 2012).

Bukle menyatakan kadar air dalam suatu produk pangan dapat mempengaruhi mutu, kesegaran dan daya awet produk. Kadar air merupakan faktor penentu shelf time suatu produk. Semakin tinggi kadar air suatu produk pangan, maka produk tersebut semakin rentan dan daya simpan relatif tidak lama. Water activity $\left(\mathrm{a}_{\mathrm{w}}\right)$ adalah derajat aktifitas air baik kimia atau biologis dalam bahan pangan. Aktifitas air berhubungan dengan kadar air terhadap daya simpan suatu bahan. Tinggi rendahnya nilai aktifitas air mempengeruhi waktu simpan dan kualitas bahan makanan (Amanto, Siswanti, \& Atmaja, 2015; Laksono, Bintoro, \& Mulyani, 2012; Leviana \& Paramita, 2017).

Kadar air bakso ikan nila pada perlakuan $X_{0}, X_{1}$, $X_{2}$ dan $X_{3}$ secara berturut-turut adalah 63,63 persen; 63,55 persen; 63,75 persen; dan 64,07 persen. Kadar air terendah terdapat pada perlakuan $\mathrm{X}_{1}$ yaitu bakso ikan nila dengan penambahan tepung ampas tahu sebanyak 5 gram. Sedangkan kadar air bakso ikan nila tertinggi terdapat pada perlakuan $\mathrm{X}_{3}$ yaitu bakso ikan nila dengan penambahan tepung ampas tahu sebesar 15 gram. Kadar air bakso ikan nila mengalami peningkatan mulai dari $X_{1}, X_{2}$, sampai $\mathrm{X}_{3}$. Sedangkan dari $\mathrm{X}_{0}$ ke $\mathrm{X}_{1}$ kadar air bakso ikan nila mengalami penurunan. Kandungan air maksimal bakso ikan berdasarkan syarat mutu dalam SNI Bakso Ikan adalah 65 persen per 100 gram bahan (Badan Standarisasi Nasional, 2014). Sehingga dapat disimpulkan, kandungan air pada bakso ikan nila dengan penambahan tepung ampas tahu telah sesuai dengan syarat mutu bakso ikan.

Perbedaan jumlah penambahan ampas tahu berpengaruh terhadap kadar air yang dikandung oleh bakso ikan nila. Hasil analisis kandungan protein menggunakan uji Kruskal Wallis dan uji Mann Whitney menghasilkan terdapat perbedaan pada kelompok perlakuan bakso ikan nila $X_{0}$ dibandingkan $X_{3}, X_{1}$ dibandingkan $X_{2}, X_{1}$ dibandingkan $X_{3}$, serta $X_{2}$ dibandingkan $X_{3}$. Sedangkan kelompok perlakuan $\mathrm{X}_{0}$ dibandingkan $\mathrm{X}_{1}$ dan $\mathrm{X}_{0}$ dibandingkan $\mathrm{X}_{2}$ tidak terdapat perbedaan signifikan.
Ayunir menyebutkan terjadi kenaikan kadar air roti manis seiring meningkatkan tepung ampas tahu yang disubstitusikan. Kenaikan kadar air disebabkan oleh keberadaan serat pada tepung ampas tahu yang memiliki kemampuan dalam mengikat air. Serat kasar memiliki kemampuan mengikat air sehingga penambahan tepung ampas tahu dapat meningkatkan kadar air. Air yang terikat dengan serat pangan sulit diuapkan kembali meski dengan proses pengeringan. Selain itu, protein yang mudah terdenaturasi pada suhu tinggi dapat berikatan dengan air memberikan sifat hidrasi pada protein yaitu daya serat air (Ayunir Ansharullah, \& Hermanto, 2017) (Fauziyah \& Yunianta, 2019).

Kandungan protein dan serat kasar yang tinggi pada tepung ampas tahu berperan dalam meningkatkan water holding capacity (WHC) tepung ampas tahu. Water holding capacity dapat mempengaruhi tekstur dari produk. Peningkatan water holding capacity suatu produk dapat membuat tekstur produk tersebut lebih kental dan lebih keras (Fauziyah \& Yunianta, 2019).

\section{Pengaruh Penambahan Tepung Ampas Tahu terhadap Daya Terima Bakso Ikan Nila}

Pengukuran daya terima bakso ikan nila dengan penambahan tepung ampas tahu dilakukan melalui pengujian organoleptik. Pengujian organoleptik berhubungan langsung dengan selera konsumen. Produk dengan nilai gizi tinggi namun rasanya sangat tidak enak maka nilai gizinya tidak bisa dimanfaatkan karena rendahnya nilai daya terima terhadap produk tersebut (Setyaningsih, Apriyantono, \& Sari, 2010).

\section{Kenampakan}

Meilgard et al menyebutkan kenampakan merupakan aspek penting yang dapat mempengaruhi daya terima suatu produk makanan. Hal tersebut dikarenakan produk dengan kenampakan yang baik cenderung akan dianggap memiliki rasa yang enak dan kualitas yang tinggi. Secara umum kenampakan produk meliputi warna, ukuran, bentuk, dan tekstur permukaan. Dewi menjelaskan secara umum, kenampakan yang baik dari sebuah produk bakso ikan yaitu berwarna cerah, memiliki permukaan yang halus, berbentuk bulat, memiliki ukuran seragam, bersih dan tidak berongga (Nurhuda, Junianto, \& Rochima, 2017) (Tarwendah, 2017).

Berdasarkan hasil penilaian oleh panelis terhadap masing-masing bakso ikan nila kelompok perlakuan 
$\mathrm{X}_{0}, \mathrm{X}_{1}, \mathrm{X}_{2}$, dan $\mathrm{X}_{3}$ diperoleh hasil kenampakan bakso ikan nila yang paling banyak disukai adalah bakso ikan nila pada perlakuan $\mathrm{X}_{2}$ dengan penambahan tepung ampas tahu sebanyak 10 gram. Hasil uji daya terima kenampakan bakso ikan nila dianalisis menggunakan uji Friedman dan memperoleh hasil $p$ value $>\alpha$. Artinya tidak terdapat perbedaan kenampakan bakso ikan nila yang nyata di antara keempat perlakuan.

Sejalan dengan penelitian Nurhuda mengenai penambahan tepung karaginan pada bakso ikan mayung yang menghasilkan daya terima kenampakan bakso ikan mayung tidak berbeda nyata. Hal tersebut dikarenakan karakteristik warna dan jumlah penambahan tepung karaginan yang tidak banyak sehingga tidak terlalu berpengaruh pada kenampakan bakso ikan mayung (Nurhuda, Junianto, \& Rochima, 2017). Karakteristik warna tepung ampas tahu yang dihasilkan dalam penelitian ini yaitu putih agak kecoklatan. Karakteristik warna yang dimiliki tepung ampas tahu dan jumlah penambahan tepung ampas tahu pada keempat kelompok perlakuan tidak jauh berbeda sehingga tidak terlalu berkontribusi dalam perubahan kenampakan bakso ikan nila. Tepung ampas tahu dapat memberikan warna terang, tekstur padat, dan menurunkan penyusutan produk akibat pemasakan (Hanum, 2016). Secara umum, kenampakan bakso ikan nila telah sesuai dengan ciriciri kenampakan bakso ikan yang baik.

\section{Aroma}

Aroma merupakan salah satu faktor penting dalam penerimaan panelis terhadap suatu produk pangan. Apabila aroma suatu produk pangan tidak disukai oleh panelis, maka hal tersebut dapat menurunkan selera makan sekaligus menurunkan daya terima panelis terhadap produk tersebut. Selain itu, aroma dapat menjadi tolak ukur kelayakan suatu produk pangan. Penilaian aroma merupakan penilaian subjektif yang membutuhkan sensitifitas dalam merasa dan mencium produk pangan yang dinilai (Permatasari \& Adi, 2018; Putri \& Nita, 2018). Dewi menjelaskan ciri-ciri bakso ikan yang baik memiliki aroma khas ikan segar rebus yang dominan sesuai ikan yang digunakan dan beraroma bumbu tanpa ada bau tengik, amis, masam, besi atau busuk (Nurhuda, Junianto, \& Rochima, 2017).

Berdasarkan hasil penilaian oleh panelis terhadap masing-masing bakso ikan nila kelompok perlakuan $X_{0}, X_{1}, X_{2}$, dan $X_{3}$, diperoleh hasil aroma bakso ikan nila yang paling banyak disukai adalah bakso ikan nila pada perlakuan $X_{2}$ dengan penambahan tepung ampas tahu sebanyak $10 \mathrm{gram}$. Hasil uji daya terima aroma bakso ikan nila dianalisis menggunakan uji Friedman dan uji Wilcoxon Sign Ranks Test diperoleh hasil aroma bakso ikan nila yang saling berbeda signifikan yaitu $\mathrm{X}_{2}$ dibandingkan $\mathrm{X}_{1}$.

Perbedaan tingkat kesukaan terhadap aroma dapat disebabkan oleh perbedaan jumlah penambahan tepung ampas tahu sebagai bahan baku dalam pembuatan bakso ikan nila. Aroma pada produk makanan dipengaruhi oleh senyawa volatil yang bersumber dari makanan itu sendiri. Senyawa volatil berpengaruh terhadap karakteristik flavor karena pengaruhnya terhadap karakteristik aroma suatu produk (Pratama, Rostini, \& Rochima, 2018). Ariyani meneliti tentang pengaruh penggunaan tepung kedelai terhadap karakteristik bakso jamur. Hasil penelitan menujukkan penambahan jumlah tepung kedelai berpengaruh terhadap tingkat kesukaan aroma bakso jamur. Penggunaan tepung kedelai dalam jumlah banyak berpengaruh terhadap tingkat kesukaan aroma bakso jamur (Ariyani, Effendi, \& Sutrisno, 2017). Produk bakso ikan nila yang dihasilkan memiliki aroma ikan yang khas serta bumbu-bumbu yang digunakan dalam pembuatan bakso.

\section{Rasa}

Rasa merupakan suatu ransangan yang didefinisikan oleh indera pengecap. Kombinasi rasa dan aroma dapat memberikan karakteristik cita rasa yang khas untuk setiap produk makanan. Rasa dinilai melalui kegiatan mencicipi suatu produk makanan, minuman atau obat. Rasa merupakan salah satu faktor yang menentukan tingkat penerimaan konsumen terhadap suatu produk makanan (Prayitno, Tjiptaningdyah, \& Hartati, 2018; Setyaningsih, Apriyantono, \& Sari, 2010).

Berdasarkan hasil penilaian oleh panelis terhadap masing-masing bakso ikan nila kelompok perlakuan $\mathrm{X}_{0}, \mathrm{X}_{1}, \mathrm{X}_{2}$, dan $\mathrm{X}_{3}$, diperoleh hasil rasa bakso ikan nila yang paling banyak disukai adalah bakso ikan nila pada perlakuan $\mathrm{X}_{2}$ dengan penambahan tepung ampas tahu sebanyak 10 gram. Hasil uji daya terima rasa bakso ikan nila dianalisis menggunakan uji Friedman dan uji Wilcoxon Sign Ranks Test diperoleh hasil rasa bakso ikan nila yang saling berbeda signifikan yaitu $\mathrm{X}_{0}$ dibandingkan $\mathrm{X}_{2}$.

Perbedaan tingkat kesukaan rasa dapat disebabkan adanya perbedaan jumlah tepung ampas tahu yang ditambahkan dalam pembuatan bakso 
ikan nila. Ariyani menyebutkan tingkat kesukaan rasa bakso jamur berbeda disebabkan perbedaan komposisi antar jamur merang, tepung kedelai, dan tepung pengisi (Ariyani, Effendi, \& Sutrisno, 2017). Dewi menjelaskan bakso ikan yang baik memiliki rasa khas ikan dan bumbu-bumbu yang digunakan dalam pembuatan bakso tanpa disertai rasa lainnya (Nurhuda, Junianto, \& Rochima, 2017).Secara keseluruhan, bakso ikan nila yang dihasilkan pada berbagai perlakuan memiliki rasa khas ikan dan rempah-rempah yang digunakan.

\section{Tekstur}

Tekstur merupakan sifat dari bahan makanan yang dapat dideteksi oleh mata, kulit dan mulut termasuk di dalamnya sifat kasar, sifat halus, sifat berpasir dan sebagainya. Tekstur memiliki peranan penting dalam menentukan kualitas suatu produk pangan dan berpengaruh terhadap daya terima produk tersebut. Tekstur dan konsentrasi suatu bahan akan berpengaruh terhadap cita rasa yang dihasilkan. Tekstur bakso dapat dinilai dari segi kekompakan, kekenyalan, dan kepadatan bakso (Midayanto \& Yuwono, 2014) (Nurhuda, Junianto, \& Rochima, 2017).

Berdasarkan hasil penilaian oleh panelis terhadap masing-masing bakso ikan nila kelompok perlakuan $\mathrm{X}_{0}, \mathrm{X}_{1}, \mathrm{X}_{2}$, dan $\mathrm{X}_{3}$, diperoleh hasil tekstur bakso ikan nila yang paling banyak disukai adalah bakso ikan nila pada perlakuan $\mathrm{X}_{2}$ dengan penambahan tepung ampas tahu sebanyak $10 \mathrm{gram}$. Hasil uji daya terima tekstur bakso ikan nila dianalisis menggunakan uji Friedman dan uji Wilcoxon Sign Ranks Test diperoleh hasil tekstur bakso ikan nila yang saling berbeda signifikan yaitu $\mathrm{X}_{2}$ dibandingkan $\mathrm{X}_{0}$ dan $\mathrm{X}_{3}$ dibandingkan $\mathrm{X}_{0}$.

Tekstur makanan merupakan hasil dari respon tactile sense terhadap rangsangan fisik yang timbul ketika terjadi kontak antara bagian di dalam rongga mulut dan makanan yang dikonsumsi (Tarwendah, 2017). Perbedaan tingkat kesukaan tekstur bakso ikan nila dapat disebabkan adanya perbedaan jumlah tepung ampas tahu yang ditambahkan dalam pembuatan bakso ikan nila. Nurhuda menyebutkan adanya perbedaan tekstur bakso ikan mayung dengan penambahan tepung karaginan. Semakin tinggi penambahan karaginan, kekenyalan bakso semakin meningkat. Pramuditya menjelaskan terdapat penerimaan yang lebih baik pada bakso dengan tekstur yang lebih keras karena menimbulkan sensasi yang lebih baik saat digigit dan dikunyah.
Bakso yang disukai yaitu bertekstur kenyal, tidak terlalu keras dan tidak terlalu lunak (Pramuditya \& Yuwono, 2014). Dewi menjelaskan tekstur bakso ikan yang baik ciri-cirinya harus kompak elastis, tidak liat atau membal, tidak terkandung duri atau tulang, tidak lembek, tidak berair, dan tidak rapuh (Nurhuda, Junianto, \& Rochima, 2017). Secara umum, tekstur bakso ikan nila yang dihasilkan pada berbagai kelompok perlakuan sudah memenuhi kriteria bakso ikan yang baik.

\section{Peranan Bakso Ikan Nila dengan Penambahan Tepung Ampas Tahu dalam Pemenuhan Gizi berdasarkan AKG}

Berdasarkan Angka Kecukupan Gizi (AKG) yang diatur dalam Peraturan Menteri Kesehatan Republik Indonesia Nomor 28 Tahun 2019, kebutuhan protein kelompok umur bayi hingga 9 tahun berkisar antara 9-40 gram $/ \mathrm{kg} \mathrm{BB} /$ hari, anak-anak umur 10-18 tahun sekitar 50-75 gram $/ \mathrm{kg} \mathrm{BB/hari,} \mathrm{dan} \mathrm{orang} \mathrm{dewasa}$ kelompok umur di atas 18 tahun sekitar $64-75 \mathrm{gram} /$ $\mathrm{kg} \mathrm{BB/hari} \mathrm{(KEMENKES} \mathrm{RI,} \mathrm{2019).} \mathrm{Satu} \mathrm{buah} \mathrm{bakso}$ ikan nila setidaknya dapat menyumbang protein sebesar 4,14\% dari Angka Kecukupan Gizi (AKG) untuk kelompok umur 10-18 tahun. Sedangkan untuk kelompok umur di atas 18 tahun, satu buah bakso ikan nila dapat menyumbangkan protein setidaknya sebesar 3,57\% dari Angka Kecukupan Gizi (AKG) kelompok umur di atas 18 tahun.

Kebutuhan serat pada setiap orang berbeda. Berdasarkan Angka Kecukupan Gizi, kebutuhan serat dibedakan menurut kelompok umur. Kelompok umur bayi hingga 9 tahun berkisar antara $0-23 \mathrm{gram} / \mathrm{kg} \mathrm{BB} /$ hari, anak-anak usia 10-18 tahun sekitar 28-37 gram/ $\mathrm{kg} \mathrm{BB/hari,} \mathrm{dan} \mathrm{orang} \mathrm{dewasa} \mathrm{kelompok} \mathrm{umur} \mathrm{di} \mathrm{atas}$ 18 tahun sekitar 22-37 gram/kg BB/hari (KEMENKES $\mathrm{RI}, 2019)$. Satu buah bakso ikan nila yang paling disukai yaitu bakso ikan nila kelompok perlakuan $\mathrm{X}_{2}$ dapat menyumbang serat setidaknya sebesar $0,11 \%$ dari Angka Kecukupan Gizi (AKG) untuk kelompok umur 10-18 tahun. Sedangkan untuk orang dewasa kelompok umur di atas 18 tahun, satu buah bakso ikan nila setidaknya dapat menyumbangkan serat sebanyak 0,14\% dari Angka Kecukupan Gizi (AKG) kelompok umur di atas 18 tahun.

\section{KESIMPULAN DAN SARAN}

\section{Kesimpulan}

Kesimpulan dari penelitian ini adalah terdapat pengaruh penambahan tepung ampas tahu terhadap 
kadar protein, kadar serat, kadar air dan daya terima bakso ikan nila. Peningkatan kadar protein, serat dan air berbanding lurus dengan peningkatan jumlah tepung ampas tahu yang ditambahkan dalam bakso ikan nila. Berdasarkan hasil uji kadar protein, serat, air, dan daya terima, bakso ikan nila dengan penambahan tepung ampas tahu yang direkomendasikan adalah bakso ikan nila dengan penambahan tepung ampas tahu sebanyak 10 gram $\left(X_{2}\right)$.

\section{Saran}

Berdasarkan penelitian ini, diharapkan dengan pengolahan ampas tahu menjadi tepung ampas tahu dapat meningkatkan pemanfaatan ampas tahu dalam industri pengolahan pangan. Sehingga hasil produksi dalam industri tahu dapat dimanfaatkan secara maksimal dan tidak terdapat sisa (zero waste). Hendaknya dilakukan penelitian mengenai kandungan gizi baik mikro maupun makro seperti karbohidrat dan lemak pada bakso ikan nila dengan penambahan tepung ampas tahu.

\section{UCAPAN TERIMA KASIH}

Ucapan terimakasih disampaikan kepada seluruh pihak yang membantu penelitian ini, terutama kepada guru, staf dan siswa SD Negeri Slawu 01 serta pihak Laboratorium Analisis Pangan dan Gizi Politeknik Negeri Jember.

\section{DAFTAR PUSTAKA}

Adriani, M., \& Kartika, V. (2013). Pola Asuh Makan pada Balita dengan Status Gizi Kurang di Jawa Timur, Jawa Tengah, dan Kalimantan Tengah Tahun 2011. Buletin Penelitian Sistem Kesehatan, 16(2), 185-193.

Amanto, B. S., Siswanti, \& Atmaja, A. (2015). Kinetika Pengeringan Temu Giring (Curcuma heyneana Valeton \& van Zijp) menggunakan Cabinet Dryer dengan Perlakuan Pendahuluan Blanching. Jurnal Teknologi Hasil Pertanian, 8(2), 107-114. https://doi. org/10.20961/jthp.v0i0.12900

Aprilia, V., \& Hati, F. S. (2016). Formulasi Bubu Bayi MPASI yang Diperkaya Hidrosilat Protein Ikan Lele Dumbo (Clarias gariepinus). Jurnal Gizi dan Dietik Indonesia, 4(2), 88-96. DOI: 10.21927/ijnd.2016.4(2).88-96

Ariyani, L., Effendi, S., \& Sutrisno, A. D. (2017). Pengaruh Perbandingan Komposisi Jamur Merang (Volvariella volvaceae), Tepung Kedelai dan Tepung Pengisi terhadap Karakteristik Bakso Jamur. Retrieved Agustus 2, 2019, from Institutional Repositories \& Scientific Journals, Universitas Pasundan: http:// repository.unpas.ac.id/26924/1/ARTIKEL-LIDYA\%20 ARIYANI-123020163.pdf
Ayunir, L., Ansharullah, \& Hermanto. (2017). Pengaruh Penambahan Tepung Ampas Tahu terhadap Komposisi Kimia dan Organoleptik Roti Manis. Jurnal Sains dan Teknologi Pangan, 2(3), 542-553.

Azrimaidaliza, A. (2011). Asupan Gizi dan Penyakit Diabetes Mellitus. Jurnal Kesehatan Masyarakat, 6(1), 36-41. https://doi.org/10.24893/jkma.v6i1.86

Badan Pengawas Obat dan Makanan. (2016). Pengawasan Klaim pada Label dan Iklan Pangan Olahan. Jakarta: Badan Pengawas Obat dan Makanan.

Badan Standarisasi Nasional. (2014). SNI 7266: Bakso Ikan. Jakarta: Badan Standarisasi Nasional.

Bimantara, A., \& Anindita, N. S. (2018). Gerakan Memasyarakatkan Makan Ikan Sejak Usia Dini Melalui Pelatihan Pengolahan Ikan bagi Orang Tua Siswa Kelas I SD Muhammadiyah Wirobrajan 3 Yogyakarta. Jurnal Pengabdian Masyarakat MIPA dan Pendidikan MIPA, 2(2), 17-22.

Diana, F. M. (2010). Fungsi dan Metabolisme Protein dalam Tubuh Manusia. Jurnal Kesehatan Masyarakat, 4(1), 47-52. https://doi.org/10.24893/jkma.v4i1.43

Fairudz, A., \& Nisa, K. (2015). Pengaruh Serat Pangan terhadap Kadar Kolesterol Penderita Overweight. Majority, 4(8), 121-126.

Fauziyah, A. I., \& Yunianta. (2019). Pengaruh Perbedaan Formulasi terhadap Sifat Fisik, Kimia, dan Organoleptik pada Muffin Non Terigu. Jurnal Pangan dan Agroindustri, 7(2), 1-12.

Gunawan, M., Kuntjara, A. P., \& Sutanto, R. P. (2017). Perancangan Board Game Gerakan Memasyarakatkan Makan Ikan (Gemarikan) untuk Anak Usia 6-10 Tahun. Jurnal Desain Komunikasi Visual Adiwarna, 1, 1-10.

Hanum, M. (2016). Penggunaan Tepung Ampas Tahu sebagai Bahan Pengikat terhadap Mutu Nugget Daging Ayam Broiler. Jurnal IImiah Peternakan, 4(3), 47-52.

Indraswari, D., Ningtyias, F. W., \& Rohmawati, N. (2017). Pengaruh Penambahan Bayam (Amaranthus tricolor) pada Nugget Kaki Naga Lele (Clarias gariepinus) terhadap Kadar Zat Besi, Protein, dan Air. Penelitian Gizi dan Makanan, 40(1), 9-16. https:// doi.org/10.22435/pgm.v40i1.6429.9-16

Kaahaoao, A., Herawati, N., \& Ayu, D. F. (2017). Pemanfaatan Tepung Ampas Tahu pada Pembuatan Kukis Mengandung Minyak Sawit Merah. Jurnal Online Mahasiswa Faperta, 4(2), 1-15.

KEMENKES RI. (2019). Angka Kecukupan Gizi yang Dianjurkan untuk Masyarakat Indonesia. Jakarta: Kementerian Kesehatan Republik Indonesia.

Kementerian Kelautan dan Perikanan. (2017). GEMARIKAN (Gemar Memasyarakatkan Makan Ikan): Upaya Peningkatan Gizi Sejak Dini. Retrieved Mei 2, 2018, from Kementerian Kelautan dan Perikanan Republik Indonesia: https://kkp.go.id/djpt/ppnsungailiat/ artikel/6676-gemarikan-gemar-memasyarakatkanmakan-ikan-upaya-peningkatan-gizi-sejak-dini 
Kementerian Kesehatan RI. (2018). Tabel Komposisi Pangan Indonesia 2017. Jakarta: Kementerian Kesehatan Republik Indonesia.

Kusharto, C. M. (2006). Serat Makanan dan Peranannya bagi Kesehatan. Jurnal Gizi dan Pangan, 1(2), 45-54. https://doi.org/10.25182/jgp.2006.1.2.45-54

Laksono, M. A., Bintoro, V. P., \& Mulyani, S. (2012). Daya Ikat Air, Kadar Air, dan Protein Nugget Ayam yang Disubstitusi dengan Jamur Tiram Putih (Pleurotus ostreatus). Animal Agriculture Journal, 1(1), 685696.

Leviana, W., \& Paramita, V. (2017). Pengaruh Suhu terhadap Kadar air dan Aktivitas Air dalam Bahan pada Kunyit (Curcuma Longa) dengan Alat Pengering Electrical Oven. METANA, 13(2), 37-44. https://doi. org/10.14710/metana.v13i2.18012

Li, S., Zhu, D., Li, K., Yang, Y., Lei, Z., \& Zhang, Z. (2013). Soybean Curd Residue: Composition, Utilization, and Related Limiting Factors. ISRN Industrial Engineering, 1-8. https://doi.org/10.1155/2013/423590

Midayanto, D. N., \& Yuwono, S. S. (2014). Penentuan Atribut Mutu Tekstur Tahu untuk Direkomendasikan sebagai Syarat Tambahan dalam Standar Nasional Indonesia. Jurnal Pangan dan Agroindustri, 2(4), 259-267.

Nainggolan, O., Kristanto, A. Y., \& Edison, H. (2013). Determinan Diabetes Melitus Analisis Baseline Data Studi Kohort Penyakit Tidak Menular Bogor 2011. Buletin Penelitian Sistem Kesehatan, 16(3), 331339.

Notoadmodjo, S. (2012). Metodologi Penelitian Kesehatan. Jakarta: Rineka Cipta.

Nurhuda, H. S., Junianto, \& Rochima, E. (2017). Penambahan Tepung Karaginan terhadap Tingkat Kesukaan Bakso Ikan Manyung. Jurnal Perikanan dan Kelautan, 8(1), 157-164.

Pemerintah Kabupaten Jember. (2014). Potensi Peternakan Perikanan dan Kelautan Jember. Jember: Pemerintah Daerah Kabupaten Jember.

Permatasari, N. E., \& Adi, A. C. (2018). Daya Terima dan Kandungan Gizi (Energi, Protein) Gyoza yang Disubstitusi Keong Sawah (Pila ampullaceal) dan Puree Kelor (Moringa oleifera). Media Gizi Indonesia, 2(2), 62-70. https://doi.org/10.20473/mgi.v13i1.6270

Prameswari, G. N., Kurnia, A. R., \& Susilo, M. T. (2019). Peningkatan Pengetahuan Ibu melalui Penyuluhan dan Pelatihan Pembuatan Makanan Olahan Ikan. Higeia Journal of Public Health Research and Development, 3(3), 469-478. https://doi.org/10.15294/ higeia.v3i3.30046

Pramuditya, G., \& Yuwono, S. S. (2014). Penentuan Atribut Mutu Tekstur Bakso sebagai Syarat Tambahan dalam SNI dan Pengaruh Lama Pemanasan terhadap Tekstur Bakso. Jurnal Pangan dan Agroindustri, 2(4), 200-209.

Pramudya, M. R., Julianti, E., \& Lubis, L. M. (2014). Pengembangan Produk Bakso Kedelai (Soyballs) dengan Penambahan Gluten serta Pati dari Ubi Kayu, Ubi Jalar, Jagung, dan Kentang. Jurnal Rekayasa Pangan dan Pertanian, 2(2), 84-95.

Pratama, I. R., Rostini, I., \& Rochima, E. (2018). Profil Asam Amino, Asam Lemak dan Komponen Volatil Ikan Gurame Segar (Osphonemus gouramy) dan Kukus. Jurnal Pengolahan Hasil Perikanan Indonesia(21), 218-231. https://doi.org/10.17844/jphpi.v21i2.22842

Prayitno, S. A., Tjiptaningdyah, R., \& Hartati, F. K. (2018). Sifat Kimia dan Organoleptik Brownies Kukus dari Proporsi Tepung Mocaf dan Terigu. Jurnal Teknologi dan Industri Pertanian Indonesia, 10(1), 22-27. https://doi.org/10.17969/jtipi.v10i1.10162

Puspita, M. R., \& Putro, G. (2008). Hubungan Gaya Hidup terhadap Kejadian Stroke di Rumah Sakit Umum Daerah Gambiran Kediri. Buletin Penelitian Sistem Kesehatan, 11(3), 263-269.

Putri, D. A., \& Yuwono, S. S. (2016). Pengaruh Penambahan Tepung Ampas Tahu dan Jenis Koagulan pada Pembuatan Tahu Berserat. Jurnal Pangan dan Agroindustri, 4(1), 321-328.

Putri, V. D., \& Nita, Y. (2018). Uji Kualitas Kimia dan Organoleptik pada Nugger Ayam Hasil Subtitusi Ampas Tahu. Jurnal Katalisator, 3(2), 135-144. https:// doi.org/10.22216/jk.v3i2.3711

Rismayanthi, C. (2006). Konsumsi Protein untuk Peningkatan Prestasi. MEDIKORA, 2(2), 135-145.

Riyadi, N. H., Amanto, B. S., \& Basito. (2012). Kajian Karakteristik Alat Pengurangan Kadar Air Madu dengan Sistem Vakum yang Berkondensor. Jurnal Teknologi Hasil Pertanian, 5(2), 8-16. https://doi. org/10.20961/jthp.v0i0.13532

Rudini, B., \& Ayustaningwarno, F. (2013). Kadar Protein, Serat, Triptofan dan Mutu Organoleptik Kudapan Ekstrusi Jagung dengan Substitusi Kedelai. Journak of Nutrition Colllege, 2(3), 373-381. https://doi. org/10.14710/jnc.v2i3.3439

Rukmana, R., \& Herdi. (2015). Sukses Budi Daya Ikan Nila secara Intensif. Yogyakarta: Lily Publisher.

Rustika, R., \& Oemiati, R. (2014). Penyakit Jantung Koroner (PJK) dengan Obesitas di Kelurahan Kebon Kelapa, Bogor. Buletin Penelitian Sistem Kesehatan, 17(4), 385-393.

Salman, Y., Syainah, E., \& Rezkiah, R. (2018). Analisis Kandungan Protein, Zat Besi dan Daya Terima Bakso Ikan Gabus dan Daging Sapi. Jurnal Kedokteran dan Kesehatan, 14(1), 63-73. https://doi.org/10.24853/ jkk.14.1.63-73

Santoso, A. (2011). Serat Pangan (Dietary Fiber) dan Manfaatnya bagi Kesehatan. Magistra, 23(75), 3540.

Setyaningsih, D., Apriyantono, A., \& Sari, M. P. (2010). Analisis Sensori untuk Industri Pangan dan Agro. Bogor: IPB Press.

Sirait, A. M., Sulistiowati, E., Sihombing, M., Kusuma, A., \& Idayani, S. (2015). Insiden dan Faktor Risiko Diabetes Melitus pada Orang Dewasa di Kota Bogor- 
Studi Kohor Prospektif Faktor Risiko Penyakit Tidak Menular. Buletin Penelitian Sistem Kesehatan, 18(2), 151-160.

Suprapti, M. L. (2005). Pembuatan Tahu. Yogyakarta: Kanisius.

Suryandari, B. D., \& Widyastuti, N. (2015). Hubungan Asupan Protein dengan Obesitas pada Remaja. Journal of Nutrition College, 4(2), 492-498. https:// doi.org/10.14710/jnc.v4i4.10153

Susanti, R., \& Hidayat, E. (2016). Profil Protein Susu dan Produk Olahannya. Jurnal MIPA, 39(2), 98-106.

Tarwendah, I. P. (2017). Jurnal Review: Studi Komparasi Atribut Sensori dan Kesadaran Merek Produk Pangan. Jurnal Pangan dan Agroindustri, 5(2), 66-73.

United States Departement of Agriculture Food. (2010). Food Composition Database. America: United States of America.
Wati, R. (2013). Pengaruh Penggunaan Tepung Ampas Tahu sebagai Bahan Komposit terhadap Kualitas Kue Kering Lidah Kucing. Food Science and Culinary Education Journal, 2(1), 57-62. https://doi. org/10.15294/fsce.v2i1.2316

Yuliantini, E., Sari, A. P., \& Nur, E. (2015). Hubungan Asupan Energi, Lemak dan Serat dengan Rasio Kadar Kolesterol Total-HDL. Penelitian Gizi dan Makanan, 38(2), 139-147. https://doi.org/10.22435/ pgm.v.38i2.5543.139-147

Yustina, I., \& Abadi, F. R. (2012). Potensi Tepung dari Ampas Industri Pengolahan Kedelai sebagai Bahan Pangan. Seminar Nasional: Kedaulatan Pangan dan Energi, (pp. 1-9). Madura.

Zulaihah, S., \& Widajanti, L. (2012). Hubungan Kecukupan Asam Eikosapentanoat (EPA), Asam Dokosaheksanoat (DHA) Ikan dan Status Gizi dengan Prestasi Belajar Siswa. Jurnal Gizi Indonesia, 1(2), 15-25. https://doi.org/10.14710/jgi.1.2. 